\title{
Frequencies of Secretors and Non-secretors of ABH Group Substances among 1,000 Alcoholic Patients
}

\author{
F. E. CAMPS,* M.D., F.R.C.P., F.C.PATH. ; BARBARA E. DODD, $\dagger$ M.SC., PH.D. ; P. J. LINCOLN, $§ \S$ B.SC., PH.D.
}

\begin{abstract}
Cummary : The ABO blood group and secretor status $S$ of 1,000 alcoholic patients has been determined. The patients were drawn from large alcoholic units in the London area together with several small units, including rehabilitation centres, nd 127 were from Aberdeen.

The findings have been compared with appropriate controls which take into account the ethnic origin of the patients in the series. A striking disturbance of the secretor/non-secretor ratio among group A patients compared with the controls is observed. There is an increase in group $A$ non-secretors, which is almost exactly balanced by a loss of group A secretors so that the overall frequency of the group $A$ phenotype is not disturbed. It is difficult to find an acceptable explanation for these
\end{abstract} results.

\section{Introduction}

The antigens $\mathrm{A}, \mathrm{B}$, and $\mathrm{H}$ of the $\mathrm{ABO}$ blood group system are not confined to the red cells but are found in a soluble form in the body fluids. Not all individuals, however, secrete their corresponding $\mathrm{ABH}$ substances. A proportion are nonsecretors-that is, their fluids are free from or contain only trace amounts of $\mathrm{A}, \mathrm{B}$, or $\mathrm{H}$ group specific substances. In the English population this figure is about $23 \%$. It is considered that the secretion of group-specific substances is controlled by a pair of allelomorphic genes, $\mathrm{Se}$ and se. Three types of individual are therefore possible-SeSe, Sese, and sese. The first two are secretors and the third is a non-secretor.

There is an association between the secretion of $\mathrm{ABH}$ blood group substances and the Lewis blood group system in that individuals whose red cells type as $\mathrm{Le}(\mathrm{a}+\mathrm{b}-)$ fall into the nonsecretor category while those whose red cells are Le $(a-b+)$ are secretors. There are therefore available two independent tests for secretor status: (a) a test on a body fluid, usually saliva, and (b) a test for the Lewis type of the red cells. A small proportion of the population (about $6 \%$ ) have red cells which type as Le $(a-b-)$ and these are either secretors or non-secretors. Their secretor status has to be determined on their body fluids.

In 1967 we reported an increase in the incidence of nonsecretors of $\mathrm{ABH}$ blood group substances among alcoholic patients compared with the controls (Camps and Dodd, 1967). By the time 318 patients had been investigated it was seen that an increase in the number of patients who were both group A and non-secretor was largely responsible for the total increase found.

It was therefore decided to continue the investigation until 1,000 patients had been examined. These patients were drawn from three large alcoholic units in the London area, together with several smaller units, including rehabilitation centres. In addition 127 patients were from Scottish units in Aberdeen, for the collection of which we are indebted to the kindness of Dr. Colin McCance, of the Cornhill Hospital, Aberdeen.

* Professor of Forensic Medicine.

+ Senior Lecturer.

$¥$ Lecturer.

Department of Forensic Medicine, London Hospital Medical College, University of London, London E.1.

SP. J. Lincoln wishes to acknowledge a grant from the Sir Halley Stewart Trust.

\section{Materials and Methods}

Saliva Samples.-From each patient 1-2 ml. of saliva was collected. As soon as possible after collection these were placed in a boiling-water bath for 15 minutes to destroy enzymes which might interfere with the activity of the blood group substances. They were then diluted one in two with normal saline and stored frozen at $-20^{\circ} \mathrm{C}$. until required.

Antisera.-Most of the antisera used throughout the investigation were kindly supplied by Dr. R. A. Zeitlin, of the South London Regional Transfusion Centre. Specially selected anti-A and anti-B sera were used for the inhibition tests on saliva samples. $\mathrm{H}$ was detected by means of anti- $\mathrm{H}$ from Ulex europaeus. Anti-Le $\mathrm{e}^{\mathrm{a}}$ and anti-Le $\mathrm{e}^{\mathrm{b}}$ typing tests were placed in a cold-water bath at a constant temperature of $15^{\circ} \mathrm{C}$. Dolichos biflorus was used by a tile method to distinguish between subgroups $A_{1}$ and $A_{2}$.

The determination of $\mathrm{ABO}$ groups and Lewis types was carried out by well-recognized blood grouping techniques. The $\mathrm{ABH}$ content of the saliva samples was determined by a screening inhibition technique against suitably diluted anti-A, anti-B, and anti-H.

\section{Results}

Table I shows the distribution of secretors and non-secretors within the various $\mathrm{ABO}$ groups of the 1,000 alcoholic patients tested. The overall percentage of non-secretors irrespective of their $\mathrm{ABO}$ group is $32 \cdot 7$. If this is compared with the usual figure of $22.7 \%$ given for non-secretors of European origin

TABLE I.-ABO Groups and Secretor Status of 1,000 Alcoholic Patients

\begin{tabular}{|c|c|c|c|c|}
\hline & Group A & Group $O$ & $\begin{array}{l}\text { Group } B \\
\text { and } A B\end{array}$ & $\underset{\text { Unknown }}{\text { ABO Group }}$ \\
\hline 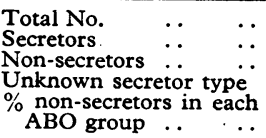 & $\begin{array}{r}380 \\
235 \\
144 \\
1 \\
37 \cdot 9\end{array}$ & $\begin{array}{r}475 \\
333 \\
141 \\
1 \\
29 \cdot 7\end{array}$ & $\begin{array}{r}130 \\
99 \\
31 \\
0 \\
23.8\end{array}$ & $\begin{array}{c}15 \\
4 \\
11 \\
0 \\
73.4\end{array}$ \\
\hline
\end{tabular}

(Race and Sanger, 1968) there is an increase of $10 \%$. Although this is not emphasized in the literature there is, however, considerable variation between the frequencies of non-secretors in different parts of the British Isles. Of the 1,000 patients described here, 404 were English, 178 Irish, and 264 Scottish. The 154 "other" alcoholics included some Welsh and others predominantly British whose exact ethnic origin was not recorded. It was therefore considered necessary to compile our own controls by visiting various parts of the British Isles. The English controls comprised 486 individuals from the staffs of the North London and South London Regional Transfusion centres and members of the staff of the London Hospital. The 981 Irish controls were obtained from blood donors from the Blood Transfusion Centres of Dublin and Belfast. The 554 Scottish controls were blood donors from Aberdeen. These gave us figures for secretor/non-secretor frequencies for comparison with the alcoholic patients. The distribution of $\mathrm{ABO}$ groups among Scottish and Irish controls was derived from three large published series because the call-up of donors at the various centres was not random for these groups (Hart, 1944 ; Kopéc, 1956 ; Hackett and Dawson, 1958). 
Table I also shows the distribution of non-secretor frequencies among the various $\mathrm{ABO}$ groups of the total number of patients tested. The group A non-secretors outstrip those of group $\mathrm{O}$ by $8.2 \%$. The 15 patients whose $\mathrm{ABO}$ group is unknown are those from whom only saliva samples were obtained.

An analysis of the results, taking into account the different ethnic groups within the British Isles, shows the same trend (Table II). There is a striking increase of group A non-

TABLE II.-Secretor Status Within the ABO Groups for Different Parts of the British Isles

\begin{tabular}{|c|c|c|c|c|c|c|c|}
\hline & & \multicolumn{2}{|c|}{ Group A } & \multicolumn{2}{|c|}{ Group 0} & \multicolumn{2}{|c|}{ Group $B$ and $A B$} \\
\hline & & $\begin{array}{l}\text { Total } \\
\text { No. }\end{array}$ & $\begin{array}{l}\% \text { Non- } \\
\text { secretors }\end{array}$ & $\begin{array}{l}\text { Total } \\
\text { No. }\end{array}$ & $\begin{array}{l}\% \text { Non- } \\
\text { secretors }\end{array}$ & $\begin{array}{l}\text { Total } \\
\text { No. }\end{array}$ & $\begin{array}{l}\% \text { Non- } \\
\text { secretors }\end{array}$ \\
\hline $\begin{array}{l}\text { English alcoholics } \\
\text { English controls } \\
\text { Irish alcoholics } \\
\text { Irish controls } \\
\text { Scottish alcoholics } \\
\text { Scottish controls } \\
\text { Other alcoholics }\end{array}$ & $\begin{array}{l}\ldots \\
\because \\
\cdots \\
\cdots \\
\cdots\end{array}$ & $\begin{array}{r}167 \\
150 \\
61 \\
289 \\
95 \\
208 \\
57\end{array}$ & $\begin{array}{l}35 \cdot 9 \\
24 \cdot 0 \\
42 \cdot 6 \\
30 \cdot 4 \\
43 \cdot 2 \\
29 \cdot 3 \\
29 \cdot 8\end{array}$ & $\begin{array}{r}185 \\
157 \\
93 \\
534 \\
137 \\
272 \\
60\end{array}$ & $\begin{array}{l}26 \cdot 5 \\
25 \cdot 5 \\
27 \cdot 9 \\
32 \cdot 6 \\
38 \cdot 7 \\
31 \cdot 6 \\
21 \cdot 6\end{array}$ & $\begin{array}{r}51 \\
36 \\
22 \\
158 \\
32 \\
67 \\
25 \\
\end{array}$ & $\begin{array}{l}27 \cdot 5 \\
16 \cdot 6 \\
31 \cdot 8 \\
27 \cdot 2 \\
21 \cdot 9 \\
25 \cdot 4 \\
13 \cdot 6 \\
\end{array}$ \\
\hline Total alcoholics & $\ldots$ & 380 & $37 \cdot 9$ & 475 & $29 \cdot 7$ & 130 & $23 \cdot 8$ \\
\hline
\end{tabular}

secretors compared with the controls. The English group show an increase of $11.9 \%$, the Irish $12.2 \%$, and the Scottish $13.9 \%$. Group $\mathrm{O}$ individuals show an increase in non-secretors of $7.1 \%$ among Scottish patients, while the Irish in fact show a decrease of $4.7 \%$ and the English an increase of $1 \%$ compared with appropriate controls.

Tests for the statistical significance of the results shown in Table II were made as follows: $\chi^{2}$ values ( 1 d.f.) were obtained for group A secretor/non-secretor frequencies in each ethnic group and the results were combined, making allowance for the direction of the differences found between alcoholics and controls, and giving $0.00001<\mathrm{P}<0.0001$. A similar calculation from the data for group $O$ secretor/non-secretor frequencies showed $\mathrm{P}>0.30$.

TABLE III.-Comparison Between Expected and Observed Frequencies of $A B O$ and Secretor Types for the Total Series

\begin{tabular}{|c|c|c|c|c|}
\hline \multicolumn{3}{|c|}{$\begin{array}{c}\text { ABO Group } \\
\text { and Secretor Status }\end{array}$} & $\begin{array}{c}\text { Expected } \\
\text { Frequencies } \\
\text { Compiled from } \\
\text { Controls }\end{array}$ & $\begin{array}{l}\text { Observed } \\
\text { Alcoholics }\end{array}$ \\
\hline $\begin{array}{l}\text { A secretors } \ldots \\
\text { A non-secretors } \ldots \\
\text { O secretors } \ldots \\
\text { O non-secretors } \\
\text { AB+B secretors } \\
\text { AB + B non-secretors } \\
\text { Unknown ABO group } \\
\text { Unknown ABO group } \\
\text { Unknown secretor statu }\end{array}$ & 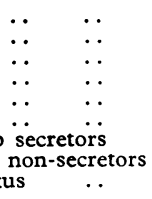 & $\begin{array}{l}\ldots \\
\cdots \\
\cdots \\
\cdots \\
\cdots \\
\cdots\end{array}$ & $\begin{array}{r}276 \\
100 \\
343 \\
140 \\
97 \\
27 \\
17\end{array}$ & $\begin{array}{r}235 \\
144 \\
333 \\
141 \\
99 \\
31 \\
4 \\
11 \\
2\end{array}$ \\
\hline Total ... & $\ldots$ & .. & 1,000 & 1,000 \\
\hline
\end{tabular}

Table III makes a comparison between the expected and observed frequencies of $\mathrm{ABO}$ and secretor types within the whole series. This enables the relative frequencies of the various groups to be studied.

The "expected" numbers in Table III were calculated from the control data on $\mathrm{ABO}$ and, secretor status distribution separately for each ethnic group, and taking into account the number of alcoholic patients of each ethnic group-that is, 404 English, 178 Irish, and 264 Scottish (Table IV). In dealing with the 154 " other" patients mentioned above as being mostly British of unknown ethnic origin, it was assumed that the proportions of the various ethnic groups among these would be similar to those found in the 846 patients whose ethnic origin was known.

The largest increase over the corresponding controls is again found in the group A non-secretors. In addition, this method of analysis shows that the corresponding decrease of secretors, instead of being equally distributed throughout all ABO groups as might be expected, is almost entirely confined to group A.
There is therefore no overall increase in the frequency of group A compared with the controls (see Table III).

Table IV divides the patients according to ethnic origin but shows the ABO group and secretor status as percentages of the total number of patients within each ethnic group. In this table groups $\mathrm{B}$ and $\mathrm{AB}$ are not included in the analysis owing to insufficient numbers. This table also gives the same information in respect of the largest individual units. Thus whatever the method of breakdown of the series the same general pattern is observed.

TABLE IV.-Blood Group Distribution and Secretor Status Analysed

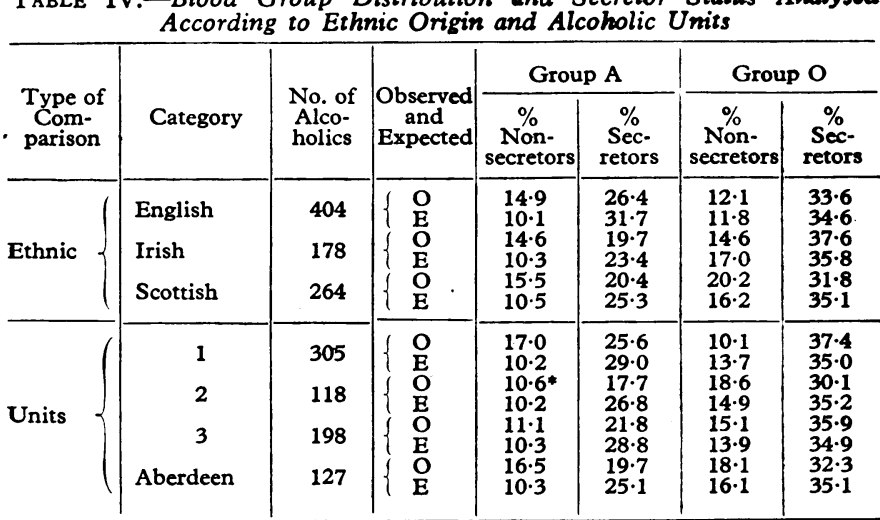

* Recent testing of patients of unknown ABO group increases this figure to 14.8.

When the distribution of $\mathrm{ABO}$ groups among the patients in the series is compared with appropriate controls there is marked similarity between them; see Table III, where the differences in secretor/non-secretor ratios, particularly of group $\mathrm{A}$, between patients and controls have not affected the overall group A frequency.

The series included 744 men, 194 women, while the sex was not recorded in 62 . The distribution of $A B O$ groups was essentially the same in both sexes. The overall percentage of non-secretors among the men is 35 , whereas that for women is 28.8. A larger series of women would be required before any firm conclusion about sex differences could be drawn.

In view of the work of Clarke et al. (1956), who noted that the incidence of duodenal ulcer is more common among nonsecretors than among secretors, a record was kept of any history of ulcers, either peptic or duodenal, among the patients in the present series. A total of 143 patients had suffered from ulcers of one type or the other. The exclusion of these from the counts did not alter the pattern of results observed: $37.4 \%$ of group A, $28.2 \%$ of group $\mathrm{O}$, and $25.2 \%$ of group $\mathrm{B}$ and $\mathrm{AB}$ patients were non-secretors (cf. Table II) when the patients with ulcers were omitted from the series.

\section{Discussion}

The term "alcoholic" is ill defined and almost certainly includes compulsive drinkers of more than one kind and even heavy drinkers who strictly should not be included as alooholic under any classification. The patients in this series were selected merely on the ground that they were found attending well-known alcoholic units or rehabilitation centres. Samples from 60 individuals collected at an annual congress of Alcoholics Anonymous have also been included. It is therefore all the more striking that such a marked disturbance of secretor/non-secretor frequencies, largely in group A, should emerge.

As mentioned above, it was not always possible to test consecutive patients attending the units. Some were lost from the series because they were unable to stay the course and had left the unit before it was possible to sample them. This may have had some bearing on the pattern of results obtained.

That there is indeed a relation between a large intake of alcohol and the secretion of $\mathrm{ABH}$ blood group substances 
would seem to be supported by the consistency of the pattern of results shown by either the series as a whole or after division according to ethnic origin, or after analysis within single alcoholic units. The general pattern of an increase of group A non-secretors among the alcoholic patients and a corresponding decrease of group A secretors is maintained.

Moreover, when the patients are divided according to ethnic origin the group A secretor/non-secretor frequencies found in each ethnic group vary in such a way as to maintain about the same differential between alcoholics of a particular ethnic group and their appropriate controls. This is well shown by the percentages of non-secretors (see Table II).

There is at the present time good evidence for a number of associations between blood groups and various diseases, particularly of the alimentary tract. These have been reviewed by Roberts (1959):

Various explanations of an association between alcoholism and $\mathrm{ABO}$ groups and secretor status come to mind: for example, a genetically determined predisposition to the disease or the existence of an enzyme or enzymes associated with the metabolism of alcohol varying with $\mathrm{ABO}$ group and secretor status (cf. the association between intestinal alkaline phosphatase and ABO blood groups described by Arfors et al., 1963). Such theories, however, would not be consistent with the finding of an almost exact balance between the increase in A non-secretors and the loss of, A secretors in the series investigated.

Such a balance points to a direct effect of alcohol on the secretor status of an individual as a cause of the disturbed secretor/non-secretor distribution. Though from most points of view this would appear to be an unacceptable theory it would best fit the experimental findings. It would require that a certain number of genetically constituted group A secretors become phenotypically non-secretors through the constant imbibition of alcohol. One difficulty is the fact that the disturbed secretor/non-secretor frequency does not apparently involve group B. In addition, whatever effect the alcohol might be supposed to exert would have to be at least moderately permanent, since most of the patients were "dry" at the time of testing. Under the experimental conditions of the tests in the series no intermediate forms difficult to categorize either as secretors or as non-secretors were encountered. Moreover, since all the non-secretor alcoholic patients have the expected red cell Lewis type-that is, they are mainly $\mathrm{Le}(\mathrm{a}+\mathrm{b}-)$ and none are $\operatorname{Le}(a-b+)$-it would have to be postulated that the prolonged intake of alcohol affected the uptake of Lewis antigens by the red cells as well as the secretion of group-specific substances by the salivary glands.

Family studies might offer one solution to the problem, since the production of secretor children from the mating of a group A non-secretor alcoholic with a non-secretor spouse (of any $\mathrm{ABO}$ group) would be very interesting indeed.

It gives us pleasure to acknowledge the kind co-operation of the following: Dr. T. H. Bewley and Mr. N. H. Holmes, of Tooting Bec Hospital, London; Dr. M. M. Glatt, of St. Bernard's Hospital, Southall, Middlesex ; Dr. M. Marcowe and Mr. D. Summers, of Springfield Hospital, Tooting; Dr. J. Merry and Mr. B. E. Evans, of West Park Hospital, Epsom; and Dr. C, E. Salter and Mr. L. G. Coates, of Warlingham Park Hospital, Surrey. For the blood donor controls from Ireland and Scotland we are indebted to the kindness and helpful interest of Dr. Clare Huth and $\mathrm{Mr}$. T. Wilson, of the Northern Ireland Transfusion Service, Dr. Brodie Lewis, of the Aberdeen and North East Scotland Blood Transfusion Service, and Dr. J. P. O'Riordan, of the Dublin Blood Transfusion Board. We appreciate valuable advice from Dr. Richard Doll, formerly of the M.R.C. Statistical Research Unit, who kindly looked at our data. Dr. J. A. Heady, of the Social Medicine Research Unit, London School of Hygiene and Tropical Medicine, guided us through the statistical tests that were applied to the results.

We should like to acknowledge the technical assistance of Mrs. Marion Harris. We should also like to thank Mr. E. Regaard, who greatly contributed to the collation of the results.

\section{REFERENCES}

Arfors, K. E., Beckman, L., and Lundin, L. G. (1963). Acta Genetica et Statistica Medica, 13, 89.

Camps, F. E., and Dodd, Barbara E. (1967). British Medical Fournal, 1,30 .

Clarke, C. A., et al. (1956). British Medical fournal, 2, 725.

Hackett, W. E. R., and Dawson, G. W. P. (1958). Irish fournal of Medical Science, 6th ser., No. $387,99$.

Hart, E. W. (1944). Annals of Eugenics, 12, 89.

Kopec, Ada C. (1956). Advancement of Science, 13, 200.

Race, R. R., and Sanger, R. (1968). Blood Groups in Man, 5th ed., p. 293. Oxford, Blackwell Scientific Publications.

Roberts, J. A. F. (1959). British Medical Bulletin, 15, 129.

\title{
Spontaneous Decrease in Gastric Secretory Response to Humoral Stimuli
}

\author{
WILLIAM WATERFALL,* M.B., CH.B.
}

\begin{abstract}
Cummary : The gastric response to pentagastrin was studied over a period of seven months in a healthy 25-year-old man without symptoms or history of gastrointestinal disease. An abrupt impairment of the gastric response to several stimulants was observed one month after starting the tests. Periodic testing since that time has shown no reversion to the type of response seen during the initial period of testing. A second subject with proved chronic duodenal ulceration presented an identical change in pattern of gastric response to stimulants.

This study suggests that such a variation in the response to gastric stimulation in a subject with a normal stomach should be borne in mind when interpreting results of gastric secretory studies.
\end{abstract}

\section{Introduction}

Pentagastrin has been used to stimulate secretion of acid by continuous intravenous infusion (Wormsley et al., 1966; Multicentre Pilot Study, 1967), subcutaneous injection (Makhlouf et al., 1966; Wormsley et al., 1967), and intramuscular injection (Johnston and Jepson, 1967), and also as snuff (Wormsley, 1968 ; Jepson et al., 1968).

This study had been planned to investigate the doseresponse of a normal human stomach to gastric stimuli and to examine the effect on this response of gastric secretory inhibitors. After the first few tests, however, there was a pronounced reduction in the gastric response to all stimulants

- House-surgeon, Department of Surgery, the Royal Infirmary, Sheffield S6 3DA. 